\title{
Contributions of RNA-seq to improve in vitro embryo production (IVP)
}

\author{
Priscila Di Paula Bessa Santana ${ }^{1, \S}$, Artur Luis da Costa da Silva², Rommel Thiago Jucá Ramos², \\ Arnaldo Algaranhar Gonçalves ${ }^{3}$, Nathalia Nogueira da Costa ${ }^{3}$, Priscilla do Carmo Azevedo Ramos ${ }^{3}$, \\ Thiago Velasco Guimarães Silva ${ }^{3}$, Marcela da Silva Cordeiro ${ }^{3}$, Simone do Socorro Damasceno Santos ${ }^{3}$, \\ Otávio Mitio Ohashi ${ }^{3}$, Moysés dos Santos Miranda ${ }^{3}$ \\ ${ }^{1}$ Federal Rural University of Amazon, Capitão-Poço, Pará, Brazil. \\ ${ }^{2}$ Laboratory of Genomics and Bioinformatics, Federal University of Pará, Belém, PA, Brazil. \\ ${ }^{3}$ Laboratory of In Vitro Fertilization, Institute of Biological Science, Federal University of Pará, Belém, PA, Brazil.
}

\begin{abstract}
In Vitro Embryo Production (IVP) is widely used to improve the reproductive efficiency of livestock animals, however increasing the embryo development rates and pregnancy outcomes is still a challenge for some species. Thus, the lack of biological knowledge hinders developing specie-specific IVP protocols. Therefore, the contributions of RNA-seq to generate relevant biological knowledge and improve the efficiency of IVP in livestock animals are reviewed herein.
\end{abstract}

Keywords: biomarker genes, in vitro embryo production, livestock animals, RNA-seq.

\section{Introduction}

In Vitro Embryo Production (IVP) is a reproductive biotechnology that may be used to increase genetic gains in short generation intervals (Kasinathan et al., 2015), to preserve genetic diversity and to treat infertility (Comizzoli et al., 2010; Lima et al., 2013). However, improving the efficiency of IVP is a challenge in many species due to biological and technical aspects (Paramio and Izquierdo, 2014). One technical aspect is the composition of the in vitro culture media, and some biological aspects are the oocyte and embryo quality (Lonergan et al., 2006).

IVP efficiency relies on adapting the in vitro conditions to meet the biological requirements of each specie (De Souza-Fabjan et al., 2014; Grupen, 2014), which has not been done properly in many livestock animals, thus resulting in huge IVP efficiency variation. This was observed by comparing the rate of embryo development as an efficiency ratio (Fig. 1). In cattle, IVP efficiency varies from 42 to $50 \%$ (Costa et al., 2013; Santana et al., 2014a; b). However, the efficiency is lower for sheep (26-35\%) (Shirazi et al., 2012; Mara et al., 2013; Naderi et al., 2016), buffalos (15-22\%) (Di Francesco et al., 2011; Kumar et al., 2012; Gasparrini et al., 2014), pigs (13-22\%) (Yoshioka et al., 2012; Nguyen et al., 2015; Spate et al., 2015), and goats (10-19\%) (KątskaKsiążkiewicz et al., 2007; Rodríguez-Dorta et al., 2007; Masudul Hoque et al., 2012). Long time research in IVP improvements certainly correlates with the high efficiency observed in cattle (Parrish, 2014), and also indicate that IVP may be potentially improved in other livestock animals if their biological requirements could be addressed.
The transcriptome of gametes and embryos has currently generated relevant biological information used to develop more suitable in vitro culture media for oocyte maturation and embryo culture (Prather et al., 2014), in addition to defining molecular markers of oocyte, sperm and embryo quality (Kropp and Khatib, 2015; Reyes et al., 2015; Kropp et al., 2017, Gilchrist et $a l ., 2016)$ based on the transcriptomic profile of coding and non-coding RNAs. Thus, herein we discuss the current biological knowledge of gametes and embryos generated by Next Generation Sequence (NGS) technologies, and how this knowledge has been applied to improve IVP in livestock animals.

\section{Overview of high-throughput sequencing technologies to generate transcriptome data}

The transcriptome is the whole set of transcripts in the cell and can be generated using hybridization (microarray) and Next Generation Sequencing (NGS) of RNA (RNA-seq). The main applications of transcriptome studies are to catalog mRNAs and non-coding RNAs, to infer alternative splicing events, to identify new genes, to analyse differential expression and to build coexpression networks (Wang et al., 2009; Han et al., 2015).

For microarray, the mRNA is first isolated and hybridized in a complementary and specific manner to the cDNA probes, therefore each time hybridization occurs can be identified by the fluorescence reading. Each probe is a nucleotide sequence complementary to the target gene, so it is required to know the genomic sequences of the target gene in order to build the probes; in the case the genome is not available, then the use of the microarray assay would be impaired (Pariset et al., 2009). This, added to the fact that the microarray slide can contain a limited number of custom probes results in a very useful technique, but with need for prior knowledge that may become a limitation depending on the specie and the type of study.

In the case of the microarray for a certain specie being unavailable, RNA-seq can be used to produce datasets of expressed sequence tag (EST) necessary to design the complementary probes, and then build a new and specie-specific microarray platform (Robert et al., 2011; Tsoi et al., 2012). Other advantages over microarray consists in RNA-seq enabling the detection of low abundant transcripts and novel genetic 
variants (Huang and Khatib, 2010; Dyck et al., 2014; Zhao et al., 2014), and also that RNA-seq can be used even when the genome is not available (Salvemini et al., 2014). In this case, assembly may be done by either the de novo approach or using the genome of a closely related specie as reference (Martin and Wang, 2011).

Another good point is that NGS technologies have been continuously upgraded in order to make them more affordable (Glenn, 2011). As a result, there are many NGS platforms available that differ in several technical aspects (method of library preparation, chemistry and sequencing efficiencies), but share one feature in generating thousands of reads (Liu et al., 2012). Affordable cost and high efficiency may be related to the increasing number of sequenced genomes available in online Databases (see www.ncbi.nlm.nih.gov/genbank/statistics), as well as the number of transcriptomes in public repositories such as GEO (Gene Expression Omnibus, www.ncbi.nlm.nih.gov/ geo) and SRA (Sequence Read Archive, www.ncbi.nlm.nih.gov/sra).

The amount of RNA-seq studies of livestock animals aimed at reproduction biotechnology aspects has also increased over the years. RNA-seq has been predominantly performed with $\mathrm{SOLiD}^{\mathrm{TM}}$, Ion ${ }^{\mathrm{TM}}$ and
Illumina $^{\mathrm{TM}}$ platforms, mainly to compare the transcriptome profile of mRNAs and miRNAs in different cell types and conditions (differential expression analysis). In the following sections we discuss some RNA-seq applications with differential expression analysis such as the study of non-invasive biomarkers of oocyte competence, sperm and embryo quality, the onset of Embryo Genome Activation (EGA), study of oocyte maturation and embryo development, as well as the effects of In Vitro Fertilization (IVF) on these processes (Tab.1).

\section{Transcriptomic profile of gametes and embryos}

Next, how RNA-seq studies have been applied to describe novel remarks in reproductive biology issues are reviewed, such as the genetic mechanisms of oocyte maturation, development and metabolism of preimplantation embryos, and the effects of in vitro conditions on gametes and embryos. Furthermore, the use of RNA-seq to identify molecular markers of oocyte, sperm and embryo quality are reviewed in the following sections and are summarized in Table 2 . Lastly, how this knowledge has been used to improve IVP is presented.

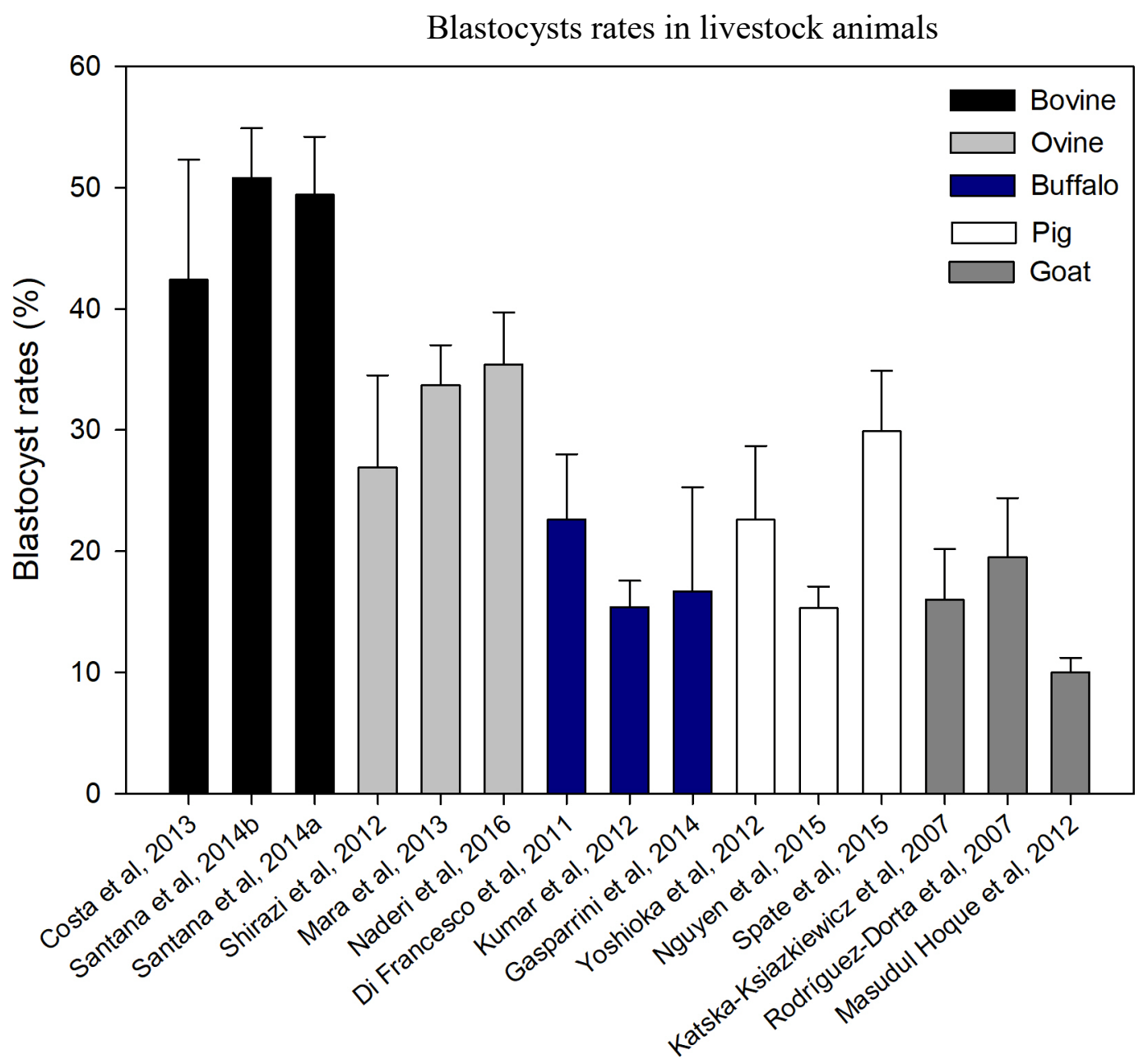

Figure 1. Efficiency of IVEP, measured in terms of blastocyst rates (total number of blastocysts divided by the total number of CCOs) in different livestock animals. 
Table 1. Aplications and brief summary of RNA-seq studies in livestock animals.

\begin{tabular}{|c|c|c|c|c|}
\hline $\begin{array}{l}\text { Applications of } \\
\text { RNA-seq }\end{array}$ & Reference & Specie & RNA-seq plataform & Brief summary of experimental design \\
\hline \multirow{2}{*}{$\begin{array}{l}\text { Produce dataset of } \\
\text { EST to design } \\
\text { probes and a new } \\
\text { microarray platform }\end{array}$} & $\begin{array}{l}\text { Robert et al. } \\
(2011)\end{array}$ & Bovine & $\begin{array}{l}\text { Genome Sequencer FLX, } \\
454 \text { Life Sciences }\end{array}$ & $\begin{array}{l}\text { Sequencing of germinal vesicle oocyte, } 2-, 4-, 8-, 16 \text {-cells, } \\
\text { morula, blastocyst and hatched blastocyst produced in vitro } \\
\text { and derived in vivo }\end{array}$ \\
\hline & Tsoi et al. (2012) & Porcine & $\begin{array}{l}\text { Genome Sequencer FLX, } \\
454 \text { Life Sciences }\end{array}$ & $\begin{array}{l}\text { Sequencing of germinal vesicle, metaphase II oocyte, 2-, 4-, } \\
8-, \text { morula, expanded and hatched blastocyst produced in } \\
\text { vitro and derived in vivo }\end{array}$ \\
\hline \multirow{4}{*}{$\begin{array}{l}\text { Study oocyte } \\
\text { competence }\end{array}$} & $\begin{array}{l}\text { Macaulay et al. } \\
\text { (2014) }\end{array}$ & Bovine & Illumina, HiSeq 2000 & $\begin{array}{l}\text { Comparison of germinal vesicle versus metaphase II oocytes } \\
\text { matured in vitro }\end{array}$ \\
\hline & $\begin{array}{l}\text { Reyes et al. } \\
(2015)\end{array}$ & Bovine & Illumina, HiSeq 2000 & $\begin{array}{l}\text { Comparison of polyadenylated transcripts in germinal vesicle } \\
\text { versus metaphase II oocytes matured in vitro }\end{array}$ \\
\hline & $\begin{array}{l}\text { Macaulay et al. } \\
\text { (2016) }\end{array}$ & Bovine & Illumina, HiSeq 2000 & $\begin{array}{l}\text { Comparison of germinal vesicle versus metaphase II oocytes } \\
\text { in vitro matured versus total RNA found in the TZPs }\end{array}$ \\
\hline & $\begin{array}{l}\text { Gilchrist et al. } \\
\text { (2016) }\end{array}$ & Bovine & Illumina, HiSeq 2500 & $\begin{array}{l}\text { Comparison of germinal vesicle versus metaphase II oocytes } \\
\text { versus presumptive zygotes }\end{array}$ \\
\hline \multirow{3}{*}{$\begin{array}{l}\text { Study non-invasive } \\
\text { mRNA and miRNA } \\
\text { biomarkers of } \\
\text { oocyte competence }\end{array}$} & Luo et al. (2016) & Sheep & Illumina, HiSeq 2000 & $\begin{array}{l}\text { Comparison of granulosa cells isolated from animals short- } \\
\text { term dietary-restricted versus nutrient-supplemented }\end{array}$ \\
\hline & Wu et al. (2017) & Sheep & Illumina, HiSeq 2500 & $\begin{array}{l}\text { Comparison of granulosa cells isolated from prepubertal } \\
\text { versus adult superstimulated follicles }\end{array}$ \\
\hline & $\begin{array}{l}\text { Mazzoni et al. } \\
(2017)\end{array}$ & Bovine & Illumina, HiSeq 2500 & $\begin{array}{l}\text { Sequencing of granulosa cells collected at OPU prior to } \\
\text { IVEP. Follow IVEP and correlation of the blastocyst rates } \\
\text { with RNA-seq results }\end{array}$ \\
\hline \multirow{4}{*}{$\begin{array}{l}\text { Study } \\
\text { transcriptomic } \\
\text { profile and } \\
\text { molecular markers } \\
\text { of sperm quality }\end{array}$} & Card et al. (2013) & ovine & Illumina, HiSeq 2000 & Sequencing of cryopreserved spermatozoa \\
\hline & $\begin{array}{l}\text { Kropp et al. } \\
(2017)\end{array}$ & Bovine & Illumina, HiSeq 2000 & $\begin{array}{l}\text { Comparison of blastocysts derived from low-fertility versus } \\
\text { high-fertility bull (based on SCR) }\end{array}$ \\
\hline & $\begin{array}{l}\text { Selvaraju et al. } \\
\text { (2017) }\end{array}$ & Bovine & $\begin{array}{l}\text { Ion ProtonTM and Illumina, } \\
\text { HiSeq } 2000\end{array}$ & $\begin{array}{l}\text { Use of two NGS platafforms to sequence spermatozoa cells } \\
\text { obtained from fresh semen }\end{array}$ \\
\hline & $\begin{array}{l}\text { Gòdia et al. } \\
\text { (2018) }\end{array}$ & Porcine & Illumina, HiSeq 2000 & $\begin{array}{l}\text { Optimization of methodological workflow for RNA-seq of } \\
\text { spermatozoa from fresh semen }\end{array}$ \\
\hline \multirow{4}{*}{$\begin{array}{l}\text { Study the onset of } \\
\text { EGA }\end{array}$} & $\begin{array}{l}\text { Ostrup et al. } \\
\text { (2013) }\end{array}$ & Porcine & SOLiD, Applied Biosystems & $\begin{array}{l}\text { Comparison of } 2 \text { - and } 4 \text {-cells embryos in vitro produced } \\
\text { versus in vivo derived }\end{array}$ \\
\hline & Graf et al. (2014) & Bovine & Illumina, GAIIx & $\begin{array}{l}\text { Comparison of germinal vesicle oocyte, metaphase II oocyte, } \\
4-, 8-, 16 \text {-cells and blastocysts produced in vitro }\end{array}$ \\
\hline & Jiang et al. (2014) & Bovine & SOLiD, Applied Biosystems & $\begin{array}{l}\text { Comparison of metaphase II oocyte, 2-, 4-, 8-, 16-cells, early } \\
\text { morula, late morula and blastocyst derived in vivo }\end{array}$ \\
\hline & Jiang et al. (2015) & $\begin{array}{l}\text { Bovine, } \\
\text { human, mice } \\
\text { and pig }\end{array}$ & $\begin{array}{l}\text { RNA-seq data downloaded } \\
\text { from online database }\end{array}$ & $\begin{array}{l}\text { Comparison of metaphase II oocyte, 2-, 4-, 8-, 16-cells, early } \\
\text { morula, late morula and blastocyst derived in vivo }\end{array}$ \\
\hline \multirow{7}{*}{$\begin{array}{l}\text { Study the IVF } \\
\text { effects on embryo } \\
\text { development }\end{array}$} & $\begin{array}{l}\text { Bauer et al. } \\
(2010)\end{array}$ & Porcine & Illumina, GAIIx & $\begin{array}{l}\text { Comparison of blastocysts in vivo derived versus collected } \\
\text { from uterus at 2-4-cells further in vitro cultured until } \\
\text { blastocyst stage }\end{array}$ \\
\hline & $\begin{array}{l}\text { Huang and Khatib } \\
(2010)\end{array}$ & Bovine & Illumina, GAIIx & $\begin{array}{l}\text { Comparison of fully developed in vitro blastocyst versus } \\
\text { arrested embryos (failed to develop from morula to blastocys } \\
\text { stage) }\end{array}$ \\
\hline & $\begin{array}{l}\text { Redel et al. } \\
\text { (2012) }\end{array}$ & Porcine & Illumina, GAIIx & $\begin{array}{l}\text { Comparison of embryos in vitro cultured in low or high } \mathrm{O} 2 \\
\text { atmospheres }\end{array}$ \\
\hline & & Bovine & Illumina, Hiseq 2000 & $\begin{array}{l}\text { Comparison of in vitro and in vivo blastocysts with similar } \\
\text { quality grade }\end{array}$ \\
\hline & Cao et al. (2014) & Porcine & $\begin{array}{l}\text { SOLiD 4, Applied } \\
\text { Biosystems }\end{array}$ & $\begin{array}{l}\text { Comparison of 1-, 2-, 4-, 8-cells, morula and blastocysts in } \\
\text { vivo derived versus produced in vitro using SCNT } \\
\text { biotechnology }\end{array}$ \\
\hline & Hera et al. (2016) & Bovine & Illumina, HiSeq 2500 & $\begin{array}{l}\text { Comparison of blastocysts in vitro produced in serum- } \\
\text { containing media versus serum free-media versus blastocysts } \\
\text { derived in vivo }\end{array}$ \\
\hline & $\begin{array}{l}\text { Milazzoto et al. } \\
(2016)\end{array}$ & Bovine & Illumina, HiSeq 2000 & $\begin{array}{l}\text { Comparison of slow and fast-cleavage embryos in vitro } \\
\text { produced versus embryos derived in vivo }\end{array}$ \\
\hline \multirow{2}{*}{$\begin{array}{l}\text { Study non-invasive } \\
\text { mRNA and miRNA } \\
\text { biomarkers of } \\
\text { embryo quality }\end{array}$} & $\begin{array}{l}\text { Kropp et al. } \\
(2014)\end{array}$ & Bovine & Illumina, GAIIx & $\begin{array}{l}\text { Comparison of media conditioned by fully developed } \\
\text { blastocysts versus arrested embryos (failed to develop from } \\
\text { morula to blastocyst) }\end{array}$ \\
\hline & $\begin{array}{l}\text { Kropp and Khatib } \\
\text { (2015) }\end{array}$ & Bovine & Illumina, GAIIx & $\begin{array}{l}\text { Comparison of media conditioned by fully developed } \\
\text { blastocysts versus arrested embryos (failed to develop from } \\
\text { morula to blastocyst) }\end{array}$ \\
\hline
\end{tabular}


Table 2. Summary of putative biomarkers reported by RNA-seq for selection of good quality gametes and embryos.

\begin{tabular}{|c|c|}
\hline Source & Putative biomarker genes \\
\hline MII oocyte & $\begin{array}{l}C C N B 1, \text { WEE2, FBXO43, MELK, H1FOO, RALB, ZP2, IGF2R, miRNA-155, miRNA- } \\
\text { 222, miRNA-21 and miRNA-190a }\end{array}$ \\
\hline Transzonal projections & ZNF773, ZNF689, ZNF75A, ZNF664, ZNF395, FAM21 and WASF2 \\
\hline Cumulus cells & GATM, Mxl and STCl \\
\hline Spermatozoa & $\begin{array}{l}C L U, A K A P 4, P R M 1, P R M 2, P L C Z 1, C R I S P 2, P S G-1, H L A-E, D B Y, E I F 1, E I F 5 \text {, } \\
E E F 1 A 1, E E F 1 \gamma, T F B 2 M \text { and CYCS }\end{array}$ \\
\hline Blastocyst & $\begin{array}{l}\text { DNMT3A, GATA3, CD9, ATP6V0A4, FAM115C, LGALS1, SLC9A3R1, BCAM, } \\
\text { BPIFA1, PLXNA3, SHROOM2, SLC16A7, EEF2, RPL10A and RPL38 }\end{array}$ \\
\hline IVC-conditioned media & POSTN, VSNL-1, PUM2, miRNA-181a2, miRNA-196a2, miRNA-302c, and miRNA-25 \\
\hline
\end{tabular}

\section{Understanding the molecular aspects of oocyte competence and maturation}

Molecular aspects of oocyte competence deeply influence embryo development and IVP outcomes (Yuan et al., 2017). Hence, improving oocyte competence becomes a major challenge in IVP (Gilchrist and Thompson, 2007). What do we know about the cytoplasmic components that determine an oocyte's developmental potential? RNA-seq studies have been used to uncover novel markers associated with oocyte quality.

During oogenesis in the germinal vesicle stage $(\mathrm{GV})$, mammalian oocytes store several transcripts that support the development of early embryos. Afterwards, the germinal vesicle breakdown occurs during oocyte maturation and the transcriptional activity becomes silenced. At the same time, the overall RNA content decreases in the metaphase II oocytes (MII) due to mRNA translation and degradation processes (reviewed by Labrecque and Sirard, 2014).

Indeed, evidence from a RNA-seq study in bovines has confirmed that the overall RNA content decreased from GV $(10,181)$ to MII $(8,941)$ stages. Also, the cytoplasmic polyadenylation of the mRNA content which indicates the occurrence of translation during oocyte maturation has been demonstrated. The study identified 2,455 (23\%) differentially expressed genes (DEG) between immature and mature in vitro oocytes, for which $503(20 \%)$ transcripts were upregulated in MII oocytes. Most of the up-regulated transcripts were involved in cell-cycle progression (CCNB1, WEE2, FBXO43, and MELK), which were also polyadenylated indicating their translation. Therefore this suggests that part of the mRNA stored by oocytes goes to translation during in vitro maturation, probably to support meiosis resumption (Reyes et al., 2015).

However, if an oocyte becomes transcriptionally silent after germinal vesicle breakdown, how can the presence of up-regulated transcripts in MII oocytes be explained? Regarding this, a RNA-seq study in cattle reported that cumulus cells produce transcripts which can be transferred to the oocyte. Using confocal live cell imaging, the newly synthetized RNA label with $[3 \mathrm{H}]$-uridine was detected along the length of the transzonal projections, confirming the cumulus cells as a novel source of de novo transcripts to the oocyte (Macaulay et al., 2014). The RNA-seq study of the transzonal projections content identified 624 transcripts corresponding to long non-coding RNAs, uncharacterized transcripts and known mRNAs such as zinc fingers (ZNF773, ZNF689, ZNF75A, ZNF664, and ZNF395), which regulate transcription by DNA binding, and transcripts (FAM21 and $W A S F 2$ ) for actin- and cytoskeleton-related process (Macaulay et al., 2016).

To this point, some transcripts involved in modulating the cell cycle and transcription produced by either oocytes or cumulus cells seem to be important for the maturation process, and thus may be correlated with oocyte competence. The transcriptome profile of miRNAs in GV, MII (in vitro mature) and early zygotes (Gilchrist et al., 2016) in cattle also reinforces this correlation. The most abundant miRNAs during oocyte maturation were linked to target genes involved in transcription regulation by RNA polymerase II activity. Some miRNAs were up-regulated between MII and early zygote stages (miRNA-155, -222, and -21), while others were down-regulated (miRNA-190a). Considering that miRNAs mostly regulate gene expression through translation repression and mRNA degradation, any increase in its levels causes a decrease in the performance of the target transcripts (Ambros, 2001). Therefore, MII oocytes have miRNA to both increase and decrease the mRNA levels in early zygotes, which may be used as molecular biomarkers of oocyte competence if their roles in embryo development are clarified.

In summary, the transcriptome profile of mRNAs and miRNAs during maturation (Reyes et al., 2015; Gilchrist et al., 2016; Macaulay et al., 2016) all suggest the role of transcripts regulating the cell cycle and transcription as potential markers of molecular quality in oocytes.

\section{Selection of non-invasive biomarkers of oocyte competence}

The importance of the granulosa cells are widely known as being beneficial for IVP, such as in the removal of cumulus cells from Cumulus-Oocyte Complexes (COCs) which significantly decreases the maturation rate $(35.4 \%)$ compared to intact COCs (79.5\%), (Macaulay et al., 2016). Given their close relation with oocyte quality, the transcriptome profile of 
cumulus has been performed in cows (Bunel et al., 2015), sheep (Luo et al., 2016; Wu et al., 2017) and humans (Feuerstein et al., 2012) as a non-invasive strategy for evaluating the quality of oocytes.

The non-invasive methods for oocyte selection might be particularly useful for OPU (Ovum Pick-Up) IVP protocols. This is because based on the granulosa transcriptome analysis only the high-potential COCs prior to in vitro fertilization may be selected, thus increasing the embryo development rates. In cows, a microarray study compared the overall gene expression patterns in biopsies of cumulus cells collected from COCs, which were further evaluated for embryo development. The expression pattern in biopsies from COCs that developed into blastocysts was different from the COCs which failed (68 DEG). GATM, involved in amino acid metabolism and free radical scavenging, was the highly expressed gene in the blastocyst fate (Bunel et al., 2015) and might be useful as a biomarker to select high-potential COCs.

The second advantage for IVP is based on the transcriptome profile of the follicular cells making it possible to select the oocyte donors with the best quality COCs for OPU-IVP. This is due to the RNA-seq study reporting a high correlation between the gene expression patterns of follicular cells and embryo development. Regarding this, COCs from 24 Holstein cows were separately in vitro fertilized for their embryo development rates to be correlated with the profile of the respective follicular cells. As a result, 2 genes were positively associated (Mxl and STC1), which means that all the cows with higher blastocyst rates also presented both genes as up-regulated. STC1 (Stanniocalcin-1) was particularly postulated as a potential biomarker of oocyte quality due to its role in granulosa cell development (Mazzoni et al., 2017).

\section{Selecting biomarkers of sperm quality}

Spermatozoa potentially contribute to embryo development by delivering DNA, a centriole, transcription factors, signaling molecules and a variety of coding and non-coding RNAs during fertilization (reviewed by Krawetz et al., 2005). RNA-seq studies of spermatozoa have been useful to identify novel markers and verify known markers of sperm quality, as well as to investigate the correlation between sperm quality and embryo development.

The first RNA-seq in spermatozoa was reported by Card et al. (2013) in cattle, and confirmed many mRNAs found by previous microarrays such as CLU, AKAP4, PRM1, PRM2, PLCZ1, CRISP2, PSG-1, $H L A-E$ and $D B Y$. The authors found 6,166 transcripts, in which $368(\sim 6 \%)$ were considered full-length transcripts (FPKM $>100$ ), and in addition they identified transcripts that had not been reported in the previous microarrays such as translation initiation (EIF1 and EIF5) and elongation (EEF1A1 and EEF1 $\gamma$ ) factors. Among the above transcripts, CLU (clusterin), PLCZ1 (phospholipase $\mathrm{C} \zeta$ ) and PRM1 (protamine-1) have been reported as potential molecular markers of sperm quality (Selvaraju et al., 2017); their delivery by sperm into the oocyte upon fertilization also suggests their roles in embryo development (Krawetz et al., 2005). Gòdia et al. (2018) recently reported the first RNA-seq study of boar sperm. However, no conclusive evidence was generated since the methodology is still being optimized for spermatozoa purification and library preparation.

Using biomarkers may be useful for selecting high fertility bulls in IVP programs. An RNA-seq study reported a correlation between the transcriptomic profile of blastocysts and bull fertility measured by sire conception rate (Kropp et al., 2017). Despite similar morphology, gene expression patterns of embryos derived from high and low fertility sirings were different (98 DEG genes). Next, bisulfite sequencing of sperm from high and low fertility sires revealed 76 differentially methylated regions, suggesting that methylation of sperm chromatin influences the gene expression patterns of pre-implantation embryos. The genes associated with mitochondrial and cytochrome $\mathrm{C}$ functions, such as TFB2M and CYCS respectively, were upregulated in embryos fertilized with high sire conception rate bulls. In addition, TFB2M mRNA silencing significantly reduced the blastocyst rate, indicating that its expression by the derived embryos may be used as a potential biomarker to select high fertility bulls (Kropp et al., 2017). In summary, the use of RNA-seq to identify novel molecular markers of sperm quality and correlate them with embryo development may help to improve IVP outcomes by selecting highly fertile bulls.

\section{Understanding the genetic mechanisms of embryo development}

During in vitro culture (IVC) important genetic events such as the maternal-zygotic transition (MZT) and the small and large waves of embryo genome activation (EGA) take place. In fact, the maternal genome controls all aspects of embryo development until EGA through mRNA and proteins stored in the oocyte cytoplasm. MZT occurs as the embryo develops; first, the maternal mRNA is gradually eliminated, and then zygotic transcription is initiated (reviewed by Tadros and Lipshitz, 2009). Understanding MZT and EGA processes is particularly useful for IVP, since the transcriptome profile of embryos as well as the metabolic requirements completely change with their occurrence. Thus, knowing the onset of EGA is important when trying to establish an IVP protocol, as EGA timing varies among species.

Experiments with $\alpha$-amanitin and the incorporation of $[3 \mathrm{H}]$ uridine helped to define the onset of EGA at 8 to 16 cells in cattle and sheep (Telford et al., 1990), at 2 to 4 cells in buffalos (Kumar et al., 2012), and at the 4 to 8 -cell stage in pigs (Memili and First, 1998). The RNA-seq approach has introduced new strategies to identify the onset of EGA. The first approach was to detect DEG genes between embryos and oocytes. The second approach was to detect transcripts from the paternal allele using the identification of specific SNPs. Finally, the third 
approach was to detect incompletely processed transcripts identified by the presence of intronic sequences due to incomplete co-transcriptional splicing (Graf et al., 2014).

Novel strategies of RNA-seq have helped to determine that the onset of EGA occurred more prematurely than previously thought in cows. It was observed that the small EGA wave occurs at 4 to 8 cells, and the large EGA wave at 8 to 16 cells (Jiang et al., 2014). In this study, the authors compared the transcriptome profile of oocytes in metaphase II, embryos with $2,4,8$, and 16 cells, morula and blastocyst produced in vivo. About 2,845 DEG genes between all stages of development were described, in which 2,031 genes were just between the 4 to 8 -cell stages, confirming the onset of minor EGA in this period.

A RNA-seq study in pigs also helped to define that EGA occurs earlier than previously thought, which is at the 2 to 4-cell stage with 2,101 DEG genes between the stages. Transcripts related to protein synthesis were predominantly found in 2-cell embryos, indicating the translation of transcripts inherited from the oocyte. This was in contrast to the 4-cell embryos which showed transcripts for "RNA splicing and processing" and "DNA metabolic processes" in agreement with the start of transcription activity by zygotes, which is an EGA hallmark (Østrup et al., 2013).

Data availability in online databases currently provides the chance to compare the transcriptome profiles of embryos from different species, thereby being able to find similarities in their embryo development programs (Jiang et al., 2015). For this, RNA-seq data was used to perform a co-expression network analysis with all the embryo development stages from bovine, human and mouse species. Surprisingly, the comparison between the human and bovine transcriptome profiles showed more similarities than those of human and mouse, suggesting that bovine embryos are better models for human embryonic development than mouse embryos (Jiang et al., 2014).

\section{New insights about the metabolism of pre- implantation embryos}

Embryo metabolism is an important issue, especially during the IVC step. In general, they have been managed like any somatic cell in vitro culture, while a fundamental question has remained unsolved: if embryos can divide as quickly as cancer cells, is their glucose metabolism also similar? The favorable speculations in the literature (Vander Heiden et al., 2009; Krisher and Prather, 2012) were suddenly confirmed by a series of transcriptomic studies.

A RNA-seq study of in vitro blastocysts in pigs reported the expression of gene variants of hexokinase $(H K)$ and pyruvate kinase (PKM2) related to slowing the tricarboxylic acid cycle and increasing the pentose phosphate pathway; a behavior compatible to the Warburg effect (Redel et al., 2012). A RNA-seq study of in vivo produced embryos in cows also reported the metabolic behavior of the Warburg effect. Based on a comparison of the transcriptomic profiles of oocytes and different stages of pre-implantation embryos, a range of 11,488 to 12,729 genes including several metabolic pathways such as the pentoses-phosphate, glycolysis, oxidative phosphorylation, and the tricarboxylic acid cycle were identified (Jiang et al., 2014).

The Warburg effect was proposed to explain the metabolic behavior of cancer cells that mostly depend on aerobic glycolysis instead of mitochondrial oxidative phosphorylation. The behavior consequently facilitates the uptake and incorporation of nutrients into the biomass (nucleotides, amino acids and lipids) which becomes the fuel needed to produce new cells (Vander Heiden et al., 2009) and to trigger rapid cell proliferation. Hence, this consists in an advantageous metabolic adaptation to the cancer cells, and also to the developing embryo. While glucose is shifted to the Warburg effect, the hypothesis is that the embryo depends on the $\beta$-oxidation of the fatty acids to provide the required ATP for the cells (Krisher and Prather, 2012)

New insights about the metabolism of carbohydrates and fatty acids of pre-implantational embryos have encouraged studies of novel supplements in IVC media able to induce the Warburg effect in embryos. The use of PS48 (a PDK1 activator) in pigs increased blastocyst formation and the total number of cells, possibly by increasing the phosphorylation of protein kinase $\mathrm{B}(P K B / A k t)$, which activates the Warburg effect (Spate et al., 2015). Similarly, arginine added to the IVC media increased blastocyst rate and the total number of cells in pigs (Redel et al., 2015), and also blastocyst quality and hatching in bovines (Santana et al., 2014a). The putative mechanism occurred through $m$ TOR phosphorylation (mammalian target of the rapamycin complex), which also activates the Warburg effect (Redel et al., 2015). Thus, the use of supplements in IVC media for activating the Warburg effect have been shown to improve in vitro embryo development. That strategy could never be tested if the previous RNA-seq studies had not evidenced the Warburg metabolic behavior in embryos from different livestock animals.

\section{Understanding the in vitro culture influence on embryo quality}

IVC is a critical step of IVP due to specific chemical and physical conditions that allow embryo development from the zygote to the blastocyst stage. Regarding this, the intrauterine and oviduct microenvironment is considered as the "gold standard" model for IVC (Tervit et al., 1972) because its composition quickly changes in response to physiological regulation in order to provide the substances required by each stage of embryo development (Knobil et al., 2006). Given the multiplicity of embryonic development and the fluid complexity, it is reasonable to think that IVC conditions are not entirely appropriate and affect embryo quality.

It is known that morphological and molecular differences between in vitro and in vivo embryos are directly associated with sub-optimal in vitro culture 
conditions (Niemann and Wrenzycki, 2000; Lonergan et al., 2003; Lonergan et al., 2006; Rizos et al., 2008), and this has also been confirmed by high throughput technologies. A RNA-seq study in cattle compared the transcriptomic profile of in vitro and in vivo derived blastocysts which presented good quality according to International Embryo Transfer Society (IETS) standards (Stringfellow and Seidel, 1998), and as a result found 793 DEG genes (Driver et al., 2012). This result was considerably larger than a previous microarray that identified the expression of 384 genes, of which $85 \%$ (326) were differentially expressed between the conditions (Corcoran et al., 2006).

One strategy to improve the in vitro culture media is testing supplementations in media followed by the gene expression analysis of the in vitro produced embryo compared to the in vivo counterpart (Lonergan et al., 2006; VanGuilder et al., 2008). Fetal Bovine Serum (FBS) is one that is worthy of investigation. A RNA-seq study compared the transcriptome profile of bovine embryos produced in either FBS-containing or FBS-free media to the profile of in vivo blastocysts to address the effects of FBS on embryo quality (Hera et al., 2016). Surprisingly, FBS-free embryos were more similar to in vivo embryos, having five times fewer DEG genes (207) than FBS-containing embryos $(1,109)$. However, after looking at the lipid and amino acid pathway gene expression patterns, it was concluded that FBS-free and in vivo-derived embryos were still very different. This may be related to the role that high concentrations of FBS cause an accumulation of lipids and decrease cryotolerance in in vitro embryos (Abe et al., 2002).

It is known that media can affect embryo quality, and some evidence also suggests that embryos can modify their own expression in response to the media. According to RNA-seq studies, bovine embryos produced in vitro in FBS-free media showed overexpression of the cholesterol biosynthesis pathway in comparison to the in vivo derived embryos (Driver et al., 2012; Hera et al., 2016). Thus, it was speculated that there would be a mechanism to compensate the deficit of lipids in an in vitro system, where they are needed to produce membrane phospholipids and metabolic energy. This also may be related to the correlation of FBS supplementation and increased rates of blastocyst formation in in vitro culture systems (George et al., 2008). Taken together, embryos can modulate their lipid metabolism in response to the media; however, there is no consensus if it is beneficial to the in vitro embryo development.

\section{Selection of non-invasive biomarkers of embryo quality and pregnancy success}

The "gold standard" of embryo quality is successful implantation and pregnancy (Van Soom et al., 2003). But how can it be possible to know which embryo is capable of implanting and result in pregnancy before the transfer? Surprisingly, evidence from transcriptomes has shown that good-quality embryos can signal their developmental competence, so the endometrium positively selects them for establishing pregnancy (Macklon and Brosens, 2014). This so-called "selective notion" by the endometrium is reasonable, since successful implantation depends on complex interactions between embryo and endometrial cells through hormonal regulation and cross-talk of several molecular signals (reviewed by Bazer et al., 2010).

The first evidence of the endometrium "selective notion" was a microarray study of endometrial cells obtained from pregnant cows (Mansouri-Attia et al., 2009). The transcriptomic profiles of endometrial cells after the transfer of embryos produced by IVF, Artificial Insemination (AI), and Nuclear Somatic Cell Transfer (TNCS) were significantly different based on the analysis of DEG genes, suggesting that embryo quality can influence the response of the endometrium for establishing pregnancy. In humans, the different transcriptomic profile of endometrial cells exposed to media conditioned by good quality (15 DEG genes) and by non-viable embryos (449 DEG genes) also raised the correlation between embryo quality and the endometrium response (Brosens et al., 2014).

If the endometrium can select embryos, the next question is: how do embryos signal their development potential? Notably, it was shown that a serine protease released by mouse embryos (trypsin) elicits cascade effects ending up with the release of prostaglandin E2 in endometrial epithelial cells, which in turn led to decidualization and implantation (Ruan et al., 2012).

RNA-seq studies in cows identified mRNAs and miRNAs that possibly act as signal molecules, although this requires further investigation. Regarding this, 11 miRNAs (Kropp et al., 2014) and 17 mRNAs (Kropp and Khatib, 2015) were found differentially expressed in culture media samples, conditioned by the culture of arrested versus fully-developed blastocysts. Among the mRNAs secreted by embryos, at least one had been previously reported (POSTN). Ovine endometrial cells can also produce POSTN transcripts and protein, which may stimulate the attachment of trophectoderm cells in vitro (Ahn et al., 2009). Taken together, these findings raise the idea that embryos can release more than one type of signal molecule to induce endometrial response. Identifying the embryo signals and understanding how to induce their production and release will certainly open new perspectives in reproductive biology, particularly for IVP.

POSTN mRNA encodes a protein that binds to integrins to support adhesion and migration of epithelial cells, and VSNL-1 mRNA encodes a protein that modulates intracellular signaling pathways regulating the activity of adenylyl cyclase; both were found highly induced in IVC conditioned media. Hence, the inhibition of POSTN translation resulted in a significant decrease of the blastocyst rate in cows (Kropp and Khatib, 2015), confirming its pivotal role in embryo development, and also as a candidate for being a molecular marker of embryo quality. Based on this evidence, the quantification of POSTN and VSNL-1 mRNA levels in IVC media may be a potential non- 
invasive strategy to select good quality embryos, although further studies about pregnancy and calving outcomes may clarify if they are also eligible for transfer in IVP programs.

In brief, RNA-seq data has been useful to investigate molecular biomarkers of embryo quality and non-invasive strategies to select good quality embryos for transfer; taken together, these results can help select embryos that are theoretically most capable for implantation. In the long term, this may increase pregnancy rates and the efficiency of IVP in many livestock animals.

\section{Future Perspectives}

The use of biomarker genes to select competent oocytes in IVP protocols may increase the rates of blastocyst development, and help to select the best donor cows for OPU-IVP. In parallel, TNCS and transgenesis biotechnologies can also take advantage of the oocyte selection strategy to improve the blastocyst rates. Similarly, the use of biomarker genes to select good quality embryos may help to increase the outcome of IVP in terms of pregnancy rates.

Following the reports of biomarker genes, the future challenge will be correlations with embryo development and pregnancy rates. With this aim, it may be useful to use techniques to inhibit mRNA translation and verify the effect of gene function loss on embryo development (Betts et al., 2014), as well as supplement in vitro culture media with substances able to inhibit and induce their expression levels. Further, proteomic and metabolomic studies may help to clarify the posttranscriptional and translational regulation mechanisms.

\section{Acknowledgements}

We would like to thank the members of the In Vitro Fertilization Laboratory and the Genomics and Bioinformatics Laboratory for their valuable opinions on this topic.

\section{References}

Abe H, Yamashita S, Satoh T, Hoshi H. 2002. Accumulation of cytoplasmic lipid droplets in bovine embryos and cryotolerance of embryos developed in different culture systems using serum-free or serumcontaining media. Mol Reprod Dev, 61(1):57-66.

Ahn HW, Farmer JL, Bazer FW, Spencer TE. 2009. Progesterone and interferon tau regulated genes in the ovine uterine endometrium: identification of periostin as a potential mediator of conceptus elongation. Reproduction, 1(138):813-825.

Ambros V. 2001. microRNAs: tiny regulators with great potential. Cell, 28(107):823-836.

Bauer BK, Isom SC, Spate LD, Whitworth KM, Spollen WG, Blake SM, Springer GK, Murphy CN, Prather RS. 2010. Transcriptional Profiling by Deep Sequencing Identifies Differences in mRNA Transcript Abundance in In Vivo-Derived Versus In VitroCultured Porcine Blastocyst Stage Embryos. Biol
Reprod, 83(5):791-798.

Bazer FW, Wu G, Spencer TE, Johnson GA, Burghardt RC, Bayless K. 2010. Novel pathways for implantation and establishment and maintenance of pregnancy in mammals. Mol Hum Reprod, 16(3):135152.

Betts DH, Bain NT, Madan P. 2014. The p66(Shc) adaptor protein controls oxidative stress response in early bovine embryos. PloS One, 9(1):e86978.

Brosens JJ, Salker MS, Teklenburg G, Nautiyal J, Salter S, Lucas ES, Steel JH, Christian M, Chan YW, Boomsma CM, Moore JD, Hartshorne GM, Sućurović S, Mulac-Jericevic B, Heijnen CJ, Quenby S, Koerkamp MJ, Holstege FC, Shmygol A, Macklon NS. 2014. Uterine selection of human embryos at implantation. Sci Rep, 4:3894. Doi: 10.1038/srep03894.

Bunel A, Jorssen EP, Merckx E, Leroy JL, Bols PE, Sirard MA. 2015. Individual bovine in vitro embryo production and cumulus cell transcriptomic analysis to distinguish cumulus-oocyte complexes with high or low developmental potential. Theriogenology, 83(2):228237.

Cao S, Han J, Wu J, Li Q, Liu S, Zhang W, Pei Y, Ruan X, Liu Z, Wang X, Lim B, Ning L. 2014. Specific gene-regulation networks during the preimplantation development of the pig embryo as revealed by deep sequencing. BMC Genomics, 15:4. Doi.org/10.1186/1471-2164-15-4.

Card CJ, Anderson EJ, Zamberlan S, Krieger KE, Kaproth M, Sartini BL. 2013. Cryopreserved bovine spermatozoal transcript profile as revealed by highthroughput ribonucleic acid sequencing. Biology of Reproduction, 88(2):1-9.

Comizzoli P, Songsasen N, Wildt DE. 2010. Protecting and extending fertility for females of wild and endangered mammals. Cancer Treat Res, 156:87100 .

Corcoran D, Fair T, Park S, Rizos D, Patel OV, Smith GW, Coussens PM, Ireland JJ, Boland MP, Evans ACO, Lonergan P. 2006. Suppressed expression of genes involved in transcription and translation in in vitro compared with in vivo cultured bovine embryos. Reproduction, 131(4):651-660.

Costa NN, Cordeiro MS, Silva TV, Sastre D, Santana PP, Sá AL, Sampaio RV, Santos SS, Adona PR, Miranda MS, Ohashi OM. 2013. Effect of triiodothyronine on developmental competence of bovine oocytes. Theriogenology, 80(4):295-301.

De Souza-Fabjan JMG, Panneau B, Duffard N, Locatelli Y, De Figueiredo JR, Freitas VJF, Mermillod P. 2014. In vitro production of small ruminant embryos: late improvements and further research. Theriogenology, 81(9):1149-1162.

Di Francesco S, Boccia L, Campanile G, Di Palo R, Vecchio D, Neglia G, Zicarelli L, Gasparrini B. 2011. The effect of season on oocyte quality and developmental competence in Italian Mediterranean buffaloes (Bubalus bubalis). Anim Reprod Sci, 123(12):48-53.

Driver AM, Penagaricano F, Huang W, Ahmad KR, Hackbart KS, Witlbank MC, Khatib H. 2012. RNASeq analysis uncovers transcriptomic variations between 
morphologically similar in vivo- and in vitro-derived bovine blastocysts. BMC Genomics, 13(1):118.

Dyck MK, Zhou C, Tsoi S, Grant J, Dixon WT, Foxcroft GR. 2014. Reproductive technologies and the porcine embryonic transcriptome. Anim Reprod Sci, 149(1), 11-18.

Feuerstein P, Puard V, Chevalier C, Teusan R, Cadoret V, Guerif F, Houlgatte R, Royere D. 2012 Genomic assessment of human cumulus cell marker genes as predictors of oocyte developmental competence: impact of various experimental factors. PloS One, 7(7):e40449.

Gasparrini B, Neglia G, Di Palo R, Vecchio D, Albero G, Esposito L, Campanile G, Zicarelli L. 2014. Influence of oocyte donor on in vitro embryo production in buffalo. Anim Reprod Sci, 144(3-4):95101.

George F, Daniaux C, Genicot G, Verhaeghe B, Lambert P, Donnay I. 2008. Set up of a serum-free culture system for bovine embryos: embryo development and quality before and after transient transfer. Theriogenology, 69(5):612-623.

Gilchrist GC, Tscherner A, Nalpathamkalam T, Merico D, LaMarre J. 2016. MicroRNA Expression during Bovine Oocyte Maturation and Fertilization. Int J Mol Sci, 17(3):396. Doi: 10.3390/ijms17030396.

Gilchrist RB, Thompson JG. 2007. Oocyte maturation: Emerging concepts and technologies to improve developmental potential in vitro. Theriogenology, 67(1):6-15.

Gilchrist RB, Lane M, Thompson JG. 2008. Oocytesecreted factors: regulators of cumulus cell function and oocyte quality. Hum Reprod Update, 14(2):159-177.

Glenn TC. 2011. Field guide to next-generation DNA sequencers. Mol Ecol Resour, 11(5):759-769.

Gòdia M, Mayer FQ, Nafissi J, Castelló A, Rodríguez-Gil JE, Sánchez A, Clop A. 2018. A technical assessment of the porcine ejaculated spermatozoa for a sperm-specific RNA-seq analysis. Syst Biol Reprod Med, 26:1-13.

Graf A, Krebs S, Zakhartchenko V, Schwalb B, Blum H, Wolf E. 2014. Fine mapping of genome activation in bovine embryos by RNA sequencing. Proc Natl Acad Sci U S A, 111(11):4139-4144.

Grupen CG. 2014. The evolution of porcine embryo in vitro production. Theriogenology, 81(1):24-37.

Han Y, Gao S, Muegge K, Zhang W, Zhou B. 2015 Advanced Applications of RNA Sequencing and Challenges. Bioinform Biol Insights, 9(Suppl 1):29-46.

Heras S, De Coninck DIM, Van Poucke M, Goossens $K$, Bogado Pascottini $O$, Van Nieuwerburgh $F$, Deforce D, De Sutter P, Leroy JLMR, GutierrezAdan A, Peelman L, Van Soom A. 2016. Suboptimal culture conditions induce more deviations in gene expression in male than female bovine blastocysts. $B M C$ Genomics, 17:72. Doi: 10.1186/s12864-016-2393-z.

Huang W, Khatib H. 2010. Comparison of transcriptomic landscapes of bovine embryos using RNA-Seq. BMC Genomics, 11(1):711. Doi: 10.1186/1471-2164-11-711.

Jiang Z, Dong H, Zheng X, Marjani SL, Donovan DM, Chen J, Tian XC. 2015. mRNA Levels of
Imprinted Genes in Bovine In Vivo Oocytes, Embryos and Cross Species Comparisons with Humans, Mice and Pigs. Sci Rep, 5:17898. Doi:10.1038/srep17898.

Jiang Z, Sun J, Dong H, Luo O, Zheng X, Obergfell C, Tang Y, Bi J, O'Neill R, Ruan Y, Chen J, Tian X. 2014. Transcriptional profiles of bovine in vivo preimplantation development. BMC Genomics, 15(1):756. Doi: 10.1186/1471-2164-15-756.

Kasinathan P, Wei H, Xiang T, Molina JA, Metzger J, Broek D, Kasinathan S, Faber DC, Allan MF. 2015. Acceleration of genetic gain in cattle by reduction of generation interval. Sci Rep, 5:8674. Doi:10.1038/srep08674.

Kątska-Książkiewicz L, Opiela J, Ryńska B. 2007. Effects of oocyte quality, semen donor and embryo coculture system on the efficiency of blastocyst production in goats. Theriogenology, 68(5):736-744.

Knobil E, Neill JD, Hess AP, Nayak NR, Giudice LC. 2006. Knobil And Neill's Physiology of Reproduction (3nd ed). In: J.D. Neill (Ed.). St. Louis, USA: Elsevier Academic Press, p.337.

Krawetz, AS. 2005. Paternal contribution: new insights and future challenges. Nat Rev Genet, 6:633-642.

Krisher RL, Lane M, Bavister BD. 1999. Developmental Competence and Metabolism of Bovine Embryos Cultured in Semi-Defined and Defined Culture Media. Biol Reprod, 60(6):1345-1352.

Krisher RL, Prather RS. 2012. A role for the Warburg Effect in preimplantation embryo development: Metabolic modification to support rapid cell proliferation. Mol Reprod Dev, 79(5):311-20. Doi: 10.1002/mrd.22037.

Kropp J, Khatib H. 2015. mRNA fragments in in vitro culture media are associated with bovine preimplantation embryonic development. Front Genet, 6:273. Doi: 10.3389/fgene.2015.00273.

Kropp J, Salih SM, Khatib H. 2014. Expression of microRNAs in bovine and human pre-implantation embryo culture media. Front Genet, 5:91. Doi: 10.3389/fgene.2014.00091.

Kropp J, Carrillo JA, Namous H, Daniels A, Salih SM, Song J, Khatib H. 2017. Male fertility status is associated with DNA methylation signatures in sperm and transcriptomic profiles of bovine preimplantation embryos. BMC Genomics, 18(1):280. Doi: 10.1186/s12864-017-3673-y.

Kumar P, Verma A, Roy B, Rajput S, Ojha S, Anand S, Yadav P, Arora J, De S, Goswami SI, Datta TK. 2012. Effect of Varying Glucose Concentrations during In Vitro Maturation and Embryo Culture on Efficiency of In Vitro Embryo Production in Buffalo. Reprod Domest Anim, 47(2):269-273.

Labrecque R, Sirard MA. 2014. The study of mammalian oocyte competence by transcriptome analysis: progress and challenges. Mol Hum Reprod, 20(2):103-116.

Lima JS, Leão DL, Sampaio RV, Brito AB, Santos RR, Miranda MS, Ohashi OM, Domingues SFS. 2013. Embryo production by parthenogenetic activation and fertilization of in vitro matured oocytes from Cebus apella. Zygote, 21(2):162-166.

Liu L, Li Y, Li S, Hu N, He Y, Pong R, Lin D, Lu L, 
Law M. 2012. Comparison of next-generation sequencing systems. J Biomed Biotechnol, 2012:251364. Doi:10.1155/2012/251364.

Lonergan P, Fair T, Corcoran D, Evans AC. 2006. Effect of culture environment on gene expression and developmental characteristics in IVF-derived embryos. Theriogenology, 65(1):137-152.

Lonergan P, Rizos D, Gutierrez-Adan A, Fair T, Boland MP. 2003. Effect of culture environment on embryo quality and gene expression - experience from animal studies. Reprod Biomed Online, 7(6):657-663.

Luo F, Jia R, Ying S, Wang Z, Wang F. 2016. Analysis of genes that influence sheep follicular development by different nutrition levels during the luteal phase using expression profiling. Anim Genet, 47(3):354-364.

Macaulay AD, Gilbert I, Caballero J, Barreto R, Fournier E, Tossou P, Sirard MA, Clarke HJ, Khandjian ÉW, Richard FJ, Hyttel P, Robert C. 2014. The gametic synapse: RNA transfer to the bovine oocyte. Biol Reprod, 91(4):90. Doi: 10.1095/biolreprod.114.119867.

Macaulay AD, Gilbert I, Scantland S, Fournier E, Ashkar F, Bastien A, Saadi HA, Gagné D, Sirard MA, Khandjian ÉW, Richard FJ, Hyttel P, Robert C. 2016. Cumulus Cell Transcripts Transit to the Bovine Oocyte in Preparation for Maturation. Biol Reprod, 94(1):16. Doi: 10.1095/biolreprod.114.127571. Macklon NS, Brosens JJ. 2014. The human endometrium as a sensor of embryo quality. Biol Reprod, 91(4):98. Doi: 10.1095/biolreprod.114.122846.

Mansouri-Attia N, Sandra O, Aubert J, Degrelle S, Everts RE, Giraud-Delville C, Heyman Y, Galio L, Hue I, Yang X, Tian XC, Lewin HA, Renard JP 2009. Endometrium as an early sensor of in vitro embryo manipulation technologies. Proc Natl Acad Sci U S A, 106(14):5687-5692.

Mara L, Sanna D, Casu S, Dattena M, Mayorga Muñoz IM. 2013. Blastocyst rate of in vitro embryo production in sheep is affected by season. Zygote, 22:366-371.

Martin JA, Wang Z. 2011. Next-generation transcriptome assembly. Nat Rev Genet, 12(10):671682.

Masudul Hoque SA, Yahia Khandoker MAM, Kabiraj SK, Asad LY, Fakruzzaman M, Tareq KMA. 2012. Effect of Goat Follicular Fluid on in vitro Production of Embryos in Black Bengal Goats. Iranian Journal of Applied Animal Science, 2(3): 287-294.

Mazzoni G, Salleh SM, Freude K, Pedersen HS, Stroebech L, Callesen H, Hyttel P, Kadarmideen HN. 2017. Identification of potential biomarkers in donor cows for in vitro embryo production by granulosa cell transcriptomics. PLoS ONE, 12(4):e0175464.

Memili E, First NL. 1998. Developmental changes in RNA polymerase II in bovine oocytes, early embryos, and effect of alpha-amanitin on embryo development. Mol Reprod Dev, 51(4):381-389.

Milazzotto MP, Goissis MD, Chitwood JL, Annes K, Soares CA, Ispada J, Assumpção ME, Ross PJ. 2016. Early cleavages influence the molecular and the metabolic pattern of individually cultured bovine blastocysts. Mol Reprod Dev, 83(4):324-336.

Naderi MM, Borjian Boroujeni S, Sarvari A, Heidari B, Akhondi MM, Zarnani AH, Shirazi A. 2016. The Effect of Media Supplementation with Angiotensin on Developmental Competence of Ovine Embryos Derived from Vitrified-warmed Oocytes. Avicenna $\mathrm{J}$ Med Biotechnol, 8(3):139-144.

Nguyen BX, Kikuchi K, Uoc NT, Dang-Nguyen TQ, Linh NV, Men NT, Nguyen TT, Nagai T. 2015. Production of Ban miniature pig embryos by in vitro fertilization: A comparative study with Landrace. Anim Sci J, 86(5):487-493.

Niemann H, Wrenzycki C. 2000. Alterations of expression of developmentally important genes in preimplantation bovine embryos by in vitro culture conditions: implications for subsequent development. Theriogenology, 53(1):21-34.

Østrup O, Olbricht G, Østrup E, Hyttel P, Collas P, Cabot R. 2013. RNA profiles of porcine embryos during genome activation reveal complex metabolic switch sensitive to in vitro conditions. PloS One, 8(4):e61547

Paramio MT, Izquierdo D. 2014. Current Status of In Vitro Embryo Production in Sheep and Goats. Reprod Domest Anim, 49(Suppl 4):37-48.

Pariset L, Chillemi G, Bongiorni S, Romano Spica V, Valentini A. 2009. Microarrays and high-throughput transcriptomic analysis in species with incomplete availability of genomic sequences. $N$ Biotechnol, 25(5):272-279.

Parrish JJ. 2014. Bovine in vitro fertilization: in vitro oocyte maturation and sperm capacitation with heparin. Theriogenology, 81(1):67-73.

Prather R, Redel B, Whitworth K, Zhao M. 2014. Genomic profiling to improve embryogenesis in the pig. - PubMed - NCBI. Anim Reprod Sci, 149(1-2):39-45.

Redel BK, Brown AN, Spate LD, Whitworth KM, Green JA, Prather RS. 2012. Glycolysis in preimplantation development is partially controlled by the Warburg Effect. Mol Reprod Dev, 79(4):262-271.

Redel BK, Tessanne KJ, Spate LD, Murphy CN, Prather RS. 2015. Arginine increases development of in vitro-produced porcine embryos and affects the protein arginine methyltransferase-dimethylarginine dimethylaminohydrolase-nitric oxide axis. Reprod Fertil Dev, 27(4):655-666.

Reyes JM, Chitwood JL, Ross PJ. 2015. RNA-Seq profiling of single bovine oocyte transcript abundance and its modulation by cytoplasmic polyadenylation. $\mathrm{Mol}$ Reprod Dev, 82(2):103-114.

Rizos D, Clemente M, Bermejo-Alvarez P, De La Fuente J, Lonergan P, Gutiérrez-Adán A. 2008. Consequences of in vitro culture conditions on embryo development and quality. Reprod Dom Anim, 43(Suppl 4):44-50.

Robert C, Nieminen J, Dufort I, Gagné D, Grant JR, Cagnone G, Plourde D, Nivet A, Fournier É, Paquet É, Blazejczyk M, Rigault P, Juge N, Sirard M. 2011. Combining resources to obtain a comprehensive survey of the bovine embryo transcriptome through deep sequencing and microarrays. Mol Reprod Dev, 78:651664. 
Rodríguez-Dorta N, Cognié Y, González F, Poulin N, Guignot F, Touzé JL, Baril G, Cabrera F, Alamo D, Batista M, Gracia A, Mermillod P. 2007. Effect of coculture with oviduct epithelial cells on viability after transfer of vitrified in vitro produced goat embryos. Theriogenology, 68(6):908-913.

Ruan YC, Guo JH, Liu X, Zhang R, Tsang LL, Dong JDA, Chen H, Yu MK, Jiang X, Zhang XH, Fok KL, Chung YW, Huang H, Zhou WL, Chan HC. 2012. Activation of the epithelial $\mathrm{Na}+$ channel triggers prostaglandin $\mathrm{E}$ release and production required for embryo implantation. Nat Med, 18(7):1112-1117.

Salvemini M, Arunkumar KP, Nagaraju J, Sanges R, Petrella V, Tomar A, Zhang H, Zheng W, Saccone G. (2014). De Novo Assembly and Transcriptome Analysis of the Mediterranean Fruit Fly Ceratitis capitata Early Embryos. PLoS ONE, 9(12):e114191. Doi: 10.1371/journal.pone.0114191. eCollection 2014.

Santana PPB, Silva TVG, Costa NN, Da Silva BB, Carter TF, Cordeiro MDS, Da Silva BJ, Santos SSD, Herculano AM, Adona PR, Ohashi OM, Miranda MD. 2014a. Supplementation of bovine embryo culture medium with L - arginine improves embryo quality via nitric oxide production. Mol Reprod Dev, 81(10):91827. Doi: 10.1002/mrd.22387. Epub 2014 Sep 18.

Santana PPB, Carvalho CMF, Costa NN, Silva TVG, Ramos PCA, Cordeiro MS, Santos SS, Khayat AS, Ohashi OM, Miranda MS. 2014b. Effect of dexamethasone on development of in vitro-produced bovine embryos. Theriogenology, 82(1):10-16.

Selvaraju S, Parthipan S, Somashekar L, Kolte AP, Krishnan Binsila B, Arangasamy A, Ravindra JP. 2017. Occurrence and functional significance of the transcriptome in bovine (Bos taurus) spermatozoa. Sci Rep, 7:42392.

Shirazi A, Ardali MA, Ahmadi E, Nazari H, Mamuee M, Heidari B. 2012. The Effect of Macromolecule Source and Type of Media During in vitro Maturation of Sheep Oocytes on Subsequent Embryo Development. J Reprod Infertil, 13(1):13-19.

Spate LD, Brown A, Redel BK, Whitworth KM, Prather RS. 2015. PS48 can replace bovine serum albumin in pig embryo culture medium, and improve in vitro embryo development by phosphorylating AKT. Mol Reprod Dev, 82(4):315-320.

Stringfellow DA, Seidel SM. (Eds). 1998. IETS. Manual of the international embryo transfer society. Savoy, Illinois, USA: International Embryo Transfer
Society.

Tadros W, Lipshitz HD. 2009. The maternal-tozygotic transition: a play in two acts. Development, 136(18):3033-3042.

Telford NA, Watson AJ, Schultz GA. 1990. Transition from maternal to embryonic control in early mammalian development: a comparison of several species. Mol Reprod Dev, 26(1):90-100.

Tervit HR, Whittingham DG, Rowson LE. 1972. Successful culture in vitro of sheep and cattle ova. $J$ Reprod Fertil, 30(3):493-497.

Tsoi S, Zhou C, Grant JR, Pasternak JA, Dobrinsky J, Rigault P, Nieminen J, Sirard MA, Robert C, Foxcroft GR, Dyck MK. 2012. Development of a porcine (Sus scofa) embryo-specific microarray: array annotation and validation. BMC Genomics, 3(13):370. Doi: 10.1186/1471-2164-13-370.

Van Soom A, Mateusen B, Leroy J, De Kruif A. 2003. Assessment of mammalian embryo quality: what can we learn from embryo morphology? Reprod Biomed Online, 7(6):664-670.

Vander Heiden MG, Cantley LC, Thompson CB. 2009. Understanding the Warburg effect: the metabolic requirements of cell proliferation. Science, 324(5930):1029-1033.

VanGuilder HD, Vrana KE, Freeman WM. 2008. Twenty-five years of quantitative PCR for gene expression analysis. BioTechniques, 44(5):619-626.

Wang Z, Gerstein M, Snyder M. 2009. RNA-Seq: a revolutionary tool for transcriptomics. Nature Reviews. Genetics, 10(1):57-63.

Wu Y, Lin J, Li X, Han B, Wang L, Liu M, Huang J. 2017. Transcriptome profile of one-month-old lambs' granulosa cells after superstimulation. Asian-Australas $J$ Anim Sci, 30(1):20-33.

Yoshioka K, Noguchi M, Suzuki C. 2012. Production of piglets from in vitro-produced embryos following non-surgical transfer. Anim Reprod Sci, 131(1), 23-29.

Yuan Y, Spate LD, Redel BK, Tian Y, Zhou J, Prather RS, Roberts RM. 2017. Quadrupling efficiency in production of genetically modified pigs through improved oocyte maturation. Proc Natl Acad Sci $U \quad S \quad A, \quad$ 114(29):E5796-E5804. doi: 10.1073/pnas.1703998114.

Zhao S, Fung-Leung WP, Bittner A, Ngo K, Liu X. 2014. Comparison of RNA-Seq and microarray in transcriptome profiling of activated T cells. PLoS One, 9(1):e78644. Doi: 10.1371/journal.pone.0078644. 